TAZKIYA (Jurnal of Psychology)

D0l: http://dx.doi.org/I0.15408/tazkiya.v9il.19522

http://journal.uinjkt.ac.id/index.php/tazkiya

\title{
Positive and Negative Creativity: Individual and Environmental Influences on Government and Private Employees
}

\author{
Fadhilah Suralaga, Mulia Sari Dewi, Nia Tresniasari \\ Fakultas Psikologi, Universitas Islam Negeri Syarif Hidayatullah Jakarta \\ Corresponding E-mail: fadhilah.suralaga@uinjkt.ac.id
}

\begin{abstract}
Research on creativity as an attitude, thinking ability, and creative behavior developed in the education sphere is profoundly related to positive things. Meanwhile, the research for negative creativity or the allegedly dark side of creativity is still very limited both in education and in the industrial world. This study examines the influence of internal factors (personality and intelligence) and external factors (organizational climate and organizational culture) on positive and negative creativity. The sample comprised 180 government employees in a ministry office and 150 private employees at a well-known insurance company in Jakarta. The results of this study show that for government employees, positive creativity mainly influenced by internal factors, namely the openness personality type, and none of the external factors affects. Simultaneously, negative creativity influenced by external factors, particularly the goal-oriented organizational climate, and none of the internal factors affects. On the other hand, private employees have various positive creativity influenced by internal factors (such as extraversion personality and neuroticism) and also external factors (the culture of cooperation and customer orientation). In contrast, negative creativity influenced by external factors of the organization, specifically the internal process that runs within the organization.
\end{abstract}

Keywords: creativity, positive creativity, negative creativity, big five personality, intelligence

\begin{abstract}
Abstrak
Penelitian tentang kreativitas sebagai sikap, kemampuan berpikir, dan perilaku kreatif yang dikembangkan dalam dunia pendidikan sangat erat kaitannya dengan hal-hal yang positif. Sementara itu, penelitian tentang kreativitas negatif atau sisi gelap kreativitas yang disinyalir masih sangat terbatas baik di dunia pendidikan maupun di dunia industri. Penelitian ini menguji pengaruh faktor internal (kepribadian dan kecerdasan) dan faktor eksternal (iklim organisasi dan budaya organisasi) terhadap positive and negative creativity. Sampel terdiri dari 180 pegawai pemerintah di sebuah kantor kementerian dan 150 pegawai swasta di sebuah perusahaan asuransi ternama di Jakarta. Hasil penelitian ini menunjukkan bahwa untuk pegawai pemerintah, positive creativity terutama dipengaruhi oleh faktor internal yaitu tipe kepribadian keterbukaan, dan tidak ada faktor eksternal yang mempengaruhi. Secara bersamaan, negative creativity dipengaruhi oleh faktor eksternal, terutama iklim organisasi yang berorientasi pada tujuan, dan tidak ada faktor internal yang mempengaruhi. Di sisi lain, karyawan swasta memiliki berbagai positive creativity yang dipengaruhi oleh faktor internal (seperti kepribadian ekstraversi dan neurotisme) maupun faktor eksternal (budaya kerja sama dan orientasi pelanggan). Sebaliknya negative creativity dipengaruhi oleh faktor eksternal organisasi, khususnya proses internal yang berjalan di dalam organisasi.
\end{abstract}

Kata Kunci: Kreativitas, Kreativitas Positif, Kreativitas Negatif, Teori Kepribadian Model Lima Besar, Kecerdasan

TAZKIYA (Journal of Psyhology), p-ISSN: 2656-0011, e-ISSN: 2654-7244

This is an open access article under CC-BY-SA license (https://creativecommons.org/licenses/by-sa/4.0/) 


\section{Introduction}

Creativity produces a positive and negative outcome, which the latter then known as The Dark Side of Creativity (Gino \& Ariely, 2012). McLaren (1993) described the use of atomic bomb technology for war, which deviates from the purpose of its maker, as an example of negative creativity. The study of the psychological processes that underlie positive and negative creativity has increased sharply recently, however in Indonesia, there is not much research on negative creativity.

Research on creativity is very diverse because it looks at it from various perspectives. Some research focuses on creative products, cognitive processes and motivational factors behind creative work (An, 2019), contextual factors that affect creativity, and others focus on the relationship between personality and creativity factors (Gino \& Ariely, 2012).

A considerable number of existing studies and writings have defined creativity as the ability to generate new ideas or products, as well as flexibility in thinking so that it can help individuals to solve problems more effectively (Guilford, 1986; Munandar, 1977).

Besides being seen from processes and attitudes, creativity can also be seen through outcomes as explained by James, Clark and Cropanzano (1999) that creativity reflected in positive repercussions, such as employee morale, improved performance, ability to adapt to change, ways to save costs, which referred to as positive creativity. Whilst negative creativity is a creative action reflected in outcomes such as stealing, fraud, exploitation, abusing rules and policies. This explanation is used as a reference in studies on the dark side of creativity, which is then used to explain creativity in this research.

Research on creativity is mostly carried out in educational settings, even though creative activities occur in different life situations, including in the fields of industry and organizations. Paying attention to creativity in today's work environment is very important because the increase of global competition requires creativity so that organizations can continue to survive and develop (Timpe, 2002, 2017). Unfortunately, most studies on creativity in organizations only focus on the positive side of creativity, such as achievement, good innovative ideas, and creative products. Whereas in reality, the use of negative creativity results with the loss of others and for the organization, such as circumventing organizational policies, making false reports, embezzling company money, exploiting people or organizations for personal/group interests. Therefore, it is crucial to understand what psychological factors trigger positive and negative creativity in the workplace.

Individual qualities that can affect creativity, according to Amabile (1988) are personality traits, motivation, risk orientation, cognitive abilities, work expertise, work experience and naivety and perfectionism. Research by James and Asmus, (2001) found that personality and divergent thinking correlated with the type of creativity. The interaction between the two has an impact on creativity. Research by George and Zhou, 2007, and Vosburg, 1998, 2010) found a joint contribution between supervisory behaviour and mood on employee creativity.

The individual factor taken as the independent variable in this study is personality, in this case, the big five personality, which is the five-factor personality trait, the approach to seeing human through the five personality domains that have been formed using Exploratory Factor Analysis. The five factors are 
extraversion, agreeableness, conscientiousness, neuroticism, and openness to experience. (Goldberg in John \& Srivastava, 1999).

Another individual factor that has broadly studied is the relationship between intelligence and creativity. High intelligent and creativity contributed to giftedness in the Three Rings Renzulli concept. Furthermore, Miller and Tal, (2007) found that openness and intelligence traits are reliable predictors of explaining creativity. Concerning negative creativity, Gino and Ariely (2012) discovered a relationship between the ability to think creatively and dishonesty, which reinforces the dark side of creativity. In this research, the intelligence concept used is fluid intelligence because intelligence is included in internal factors so that it is expected to maintain the purity of the intentions of internal factors in this study.

Based on the findings above, it can be assumed that an empirical study of positive and negative creativity in industrial and organizational settings (workplaces) is still needed, especially to capture a small part of the phenomenon in Indonesia. In this study, the individual factors studied were personality and intelligence, while environmental factors, such as culture and organizational climate, were considered essential and covered things that were comprehensive enough to describe internal and external factors. To get a specific picture of external influences, research was organized at a ministerial office and private company. The two institutions have disparate goals, work regulations, procedures, and work appraisals which ultimately create different work climate and culture.

\section{Research Question}

The questions posed in this research are:

1. Do individual factors, and environmental factors influence positive and negative creativity among government and private employees?

2. Which individual factors (personality and intelligence) and environmental factors (climate and organizational culture), that significantly influence positive and negative creativity in both government and private employees?

Figure 1. shows the research model used to answer the research questions above. In this figure, it can be seen that each independent variable tested for its influence on the dependent variable. Such a case is done both for each group (government and private employees) and participants as a whole.

Figure 1

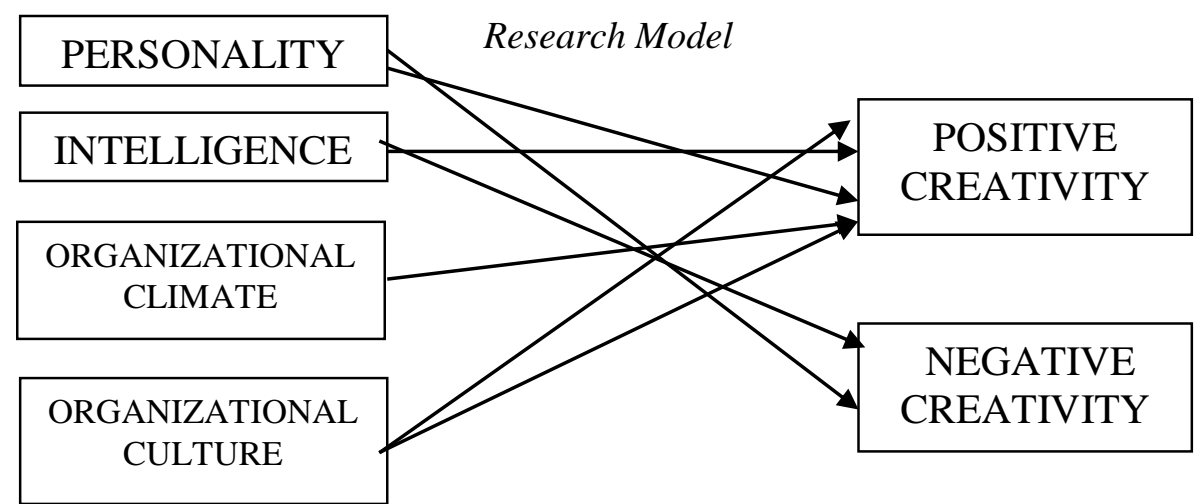




\section{Method}

\section{Design and Participants of the Study}

This study used the quantitative method with a survey design. The participants in this study came from two agencies, namely government agencies and private companies. The number of participants in this group is 150 civil servants in a ministry office and 180 permanent employees at a large private company in the insurance industry. Participants were selected using a non-probability sampling technique.

\section{Research Variable}

The dependent variable in this study consists of positive creativity and negative creativity. Meanwhile, personality (extraversion, agreeableness, conscientiousness, neuroticism, openness to experience), intelligence, organizational climate (human relations, internal process, open system, rational goal) and organizational culture (managing change, achieving goals, coordinated teamwork, customer orientation, cultural strength) is an independent variable that regressed towards positive creativity and negative creativity.

\section{Instruments}

The instrument used in the study was a questionnaire to measure The Big Five Personality, Organizational Climate, and Organizational Culture. All scales provided with 4 points of Likert Scale ranging from very unsuitable, unsuitable, suitable, and very suitable with a score of 1 to 4 for favourable items and 4 to 1 for unfavourable items. The exception is the scale measuring positive and negative creativity and to measure intelligence. Testing of construct validity of The Big Five Inventory Scale, Organizational Climate Scale, and Organizational Culture Assessment Questionaire was using Confirmatory Factor Analysis (CFA), which provided the detail below.

\section{Positive and Negative Creativity Scale}

Creativity in this research is measured using the positive-negative creativity instrument developed by Hansika Kapoor (in the Creativity Research Journal, February 2015). The measuring instruments consist of 15 situations/problems, and each of them followed by three answer choices (positive, neutral, negative). Figure 2. showed the example of items in this instrument. 
Figure 2.

\section{Item examples in Creativity Scale}

1. Anda seorang pegawai. Tim anda harus membuat desain promosi yang akan meningkatkan penjualan atas produk yang diberikan. Anda akan...

- Bekerja bersama tim untuk membuatnya.

- Merancang strategi baru yang secara halus menyampaikan bahwa produk anda lebih baik dengan menggunakan testimoni dari pelanggan yang telah berpindah pilihan.

○ Merancang strategi baru dengan melibatkan pelanggan yang telah menggunakan produk tersebut untuk menarik pelanggan baru.

2. Anda diharuskan melakukan presentasi di dalam sebuah forum, namun anda lupa tentang beberapa bagian dari topik yang akan Anda sampaikan. Anda akan...

- Tetap melakukan presentasi tanpa persiapan dan di tengah presentasi anda berpura-pura menerima telepon penting yang harus anda jawab.

- Melakukan presentasi dengan pengetahuan yang anda miliki dan mengajak audiens berpartisipasi.

- Mengaku bahwa anda lupa dan berjanji akan melakukannya di pertemuan berikutnya.

\section{The Big Five Inventory Scale}

To measure personality, the Big Five Inventory (Oliver and Srivastawa, 1999) was used that consists of 21 items, of which 15 are favourable, and six are unfavourable. Each item is measured using a Likert scale with four categories of alternative answers, namely: (1) Very Unsuitable, (2) Unsuitable, (3) Suitable, and (4) Very Suitable. The validity test is carried out on each dimension using the Confirmatory Factor Analysis technique, the results showed in Table 1.

Table 1

CFA Results on Big Five Inventory

\begin{tabular}{lcccc}
\hline Dimensions & Chi-square & $\mathrm{df}$ & $\mathrm{p}$-value & RMSEA \\
\hline Extraversion & 3.695 & 7 & 0.0546 & 0.075 \\
Agreeableness & 5.459 & 2 & 0.0653 & 0.060 \\
Conscientiousness & 0.497 & 2 & 0.7801 & 0.000 \\
Neuroticism & 5.263 & 2 & 0.0720 & 0.059 \\
Openess & 5.075 & 4 & 0.2797 & 0.024 \\
\hline
\end{tabular}

The results of CFA analysis showed all dimension that a fit model was observed. The extraversion dimension have a chi-square value $=3,695, \mathrm{P}$ - value $=0.055$. The number of items is four and all are valid. A chi-square on agreeableness dimension $=5.459, \mathrm{P}$ - value 0.065 . The number of items is four but one of them is invalid. The dimensions of conscientiousness and neuroticism have a chi-square = 0.497 and 5,263, P-values $=0.780$ and 0.072). Each dimension is measured by four items and all are 
valid. Finally, the openess to experiences dimension has a chi-square $=5.075, \mathrm{P}$-value $=0.279$. This dimension is measured by five items and all are valid.

\section{Intelligence Test}

The test used to measure intelligence was the CFIT (Culture Fair Intelligence Test), chosen considering that this tool is nonverbal. This tool was created by Raymond B. Cattel to measure fluid intelligence (the ability to analyze in abstract situations), which is free from cultural influences.

\section{The Organizational Climate Scale}

The organizational climate in this study was measured using the Organizational Climate Scale which has been validated by Patterson (2009). This scale measures 17 aspects that grouped into 4 quadrants, consisting of 34 items, of which 25 items are favorable and 9 items are unfavourable. The results of CFA analysis in the dimension of human relations has chi-square $=63,056, \mathrm{P}$-value $=0.0588$. The number of valid items is 11 out of 12 . In the internal process, it is obtained chi-square $=0.561, \mathrm{P}$-_value $=0.454$. The number of valid items is three out of four items. In the open system obtained chi-square $=$ 14,588 , P-value $=0.0677$. The number of valid items is four out of six. In the Rational Goal, the chisquare $=63.003$, P-value $=0.0577$. This dimension is measured by six items and all are valid.

Table 2

CFA Results on Organizational Climate Scale

\begin{tabular}{lcccc}
\hline Dimensions & Chi-square & df & p-value & RMSEA \\
\hline Human Relation & 63.056 & 47 & 0.0588 & 0.044 \\
Internal Process & 0.561 & 1 & 0.4539 & 0.000 \\
Open System & 14.588 & 8 & 0.0677 & 0.068 \\
Rational Goal & 62.003 & 46 & 0.0577 & 0.044 \\
\hline
\end{tabular}

\section{Organizational Culture Assessment Questionaire}

Organizational culture was measured using the Organizational Culture Assessment Questionaire developed by (Sashkin \& Rosenbach, 1996). This instrument consists of 30 items, of which 23 items are favorable and 7 items are unfavourable. CFA analysis was used to test the instrumen and the result showed that the data obtained from managing change dimension is fit with the theory designed with chi-square $=14.711$, P-value $=0.065$. Thus it is obtained information that 6 items that measure unidimensional managing change was significant which indicate that it is and hence this scale can measure what it should measure. Furthermore, each item is checked for validity with the t- test and information is obtained that 4 of the 6 items are significant. The next four items are used to estimate managing change. 
TAZKIYA (Journal of Psychology), 9(1), 2021

Table 3

CFA Results on Organizational Culture Scale

\begin{tabular}{lcccc}
\hline Dimensions & Chi-square & $\mathrm{df}$ & $\mathrm{p}$-value & RMSEA \\
\hline Managing Change & 14.711 & 8 & 0.0650 & 0.069 \\
Achieveing Goal & 12.665 & 9 & 0.1784 & 0.048 \\
Coordinated Teamwork & 6.883 & 7 & 0.4411 & 0.069 \\
Customer Orientation & 5.677 & 9 & 0.7718 & 0.000 \\
Cultural Strength & 9.701 & 7 & 0.2062 & 0.047 \\
\hline
\end{tabular}

The same analysis was done to the dimensions of achieving a goal, coordinated teamwork, customer orientation, cultural strength. In achieving a goal, a chi-square score $=12,665$, P-value 0.1784 . The number of valid items is 5 out of 6 items. Coordinated teamwork has a chi-square $=6,883, \mathrm{P}$-value $=$ 0.4411 . The number of valid items in this dimension is four out of six. In customer orientation and cultural strength, chi-square $=5,677$ and 9,701, with P-values 0.7718 and 0.2062 ). In these aforementioned two dimensions, all items are valid with a total of 6 each.

\section{Data Analysis}

The data analysis technique used to answer the research hypothesis above is multivariate regression, carried out simultaneously in two or more groups (multigroup). This analysis technique compared the effect of IV on DV in each group directly. This essay focus on the similarities and differences in parameter structures that illustrate different mechanisms for the formation of DV (Hair et al., 2006) The causes of various positive and negative creativity among government and private employees are directly comparable. The data then analyzed with MPLUS version 7.11 software (Muthen \& Muthen, 2010).

\section{Results and Discussion}

The original study involved all personality variables, yet concluded with only extraversion, openness to experience, and neuroticism because agreeableness and conscientiousness immensely corresponded with extraversion. Extraversion, openness to experience, neuroticism, IQ, internal process, open system, rational goal, achieving goals, coordinated teamwork, customer orientation, and cultural strength affect positive creativity and negative creativity. Table 4 illustrates the R-square of the regression test results. 
TAZKIYA (Journal of Psychology), 9(1), 2021

Table 4

$R$-square of all Independent Variables on Creativity

\begin{tabular}{llcc}
\hline & DV & R-square & $\mathrm{p}$ \\
\hline Government Employees & Positive Creativity & $0.092^{*}$ & 0.025 \\
& Negative Creativity & 0.055 & 0.096 \\
Private Employees & Positive Creativity & $0.115^{*}$ & 0.019 \\
& Negative Creativity & $0.101^{*}$ & 0.03 \\
\hline
\end{tabular}

*Significance at $\alpha=0.05$

As can be seen from table 1. that the R-square magnitude for government employees for positive creativity is 0.092 ( $p<0.025)$, while for negative creativity is 0.055 ( $p>0.05)$. The $r$-square for private employees for positive creativity is 0.115 ( $p<0.05$ ) while for negative creativity is $0.101(\mathrm{p}<0.05)$. Based on this value, the variations in creativity among private employees can be more illustrated than in government employees. The causes of the variation in negative creativity among government employees cannot be known from both individual factors and environmental factors involved in this study. This occurs because the variation in negative creativity among government employees is very small.

After seeing the effect of all independent variables on creativity, the next step is to examine the effect of each dimension in the independent variable on positive and negative creativity. Table 5. illustrates the regression coefficients of each independent variable on positive and negative creativity in government employees and private employees.

Table 5

Independent Variable Regression Coefficients on Positive Creativity and Negative Creativity

\begin{tabular}{lcccc}
\hline & \multicolumn{2}{c}{ Government Employees } & \multicolumn{2}{c}{ Private Employees } \\
\cline { 2 - 5 } & Positive & Negative & Positive & Negative \\
& Creativity & Creativity & Creativity & Creativity \\
\hline Extraversion & 0.06 & -0.034 & $-0.187^{*}$ & 0.123 \\
Openness to experience & $0.192^{*}$ & 0.014 & 0.16 & 0.074 \\
Neuroticism & 0.026 & 0.123 & $-0.164^{*}$ & 0.058 \\
Inteligensi & 0.042 & -0.034 & 0.133 & -0.052 \\
Internal Process & -0.069 & -0.03 & -0.012 & $-0.196^{*}$ \\
Open System & -0.037 & -0.046 & 0.042 & -0.026 \\
\hline
\end{tabular}

http://journal.uinjkt.ac.id/index.php/tazkiya 
TAZKIYA (Journal of Psychology), 9(1), 2021

\begin{tabular}{lcccc}
\hline Rational Goal & 0.062 & -0.05 & -0.092 & 0.189 \\
Achieving Goal & -0.1 & $0.257^{*}$ & -0.003 & -0.233 \\
Coordinated Teamwork & 0.037 & -0.21 & $-0.316^{*}$ & 0.275 \\
Customer Orientation & 0.233 & 0.077 & $0.313^{*}$ & -0.193 \\
Cultural Strength & -0.119 & -0.123 & 0.072 & -0.119 \\
\hline
\end{tabular}

Based on testing of the dependent variable positive creativity in government employees, the results of the individual factors that affect only personality openness are obtained. Meanwhile, there is no single environmental factor that has a significant effect.

On the other hand, when the analysis was carried out on private employee participants, it is found that the factors that influence positive creativity are personality variables, namely openness and neuroticism, as well as organizational culture, namely coordinated teamwork and customer orientation. Negative creativity in private employees is only influenced by the organizational climate, namely internal processes.

\section{Creativity in Government Employees}

Based on the test results on the group of government employees, it was found that of all independent variables studied, only the openness personality type had a significant positive effect on creativity with a coefficient of 0.192 . The coefficient which is positive indicates that employees with high openness scores also have high positive creativity. Figure 4 shows a path diagram of all dependent variables on positive and negative creativity in government employees.

\section{Figure 4}

Positive and Negative Creativity Path Diagram for Government Employees

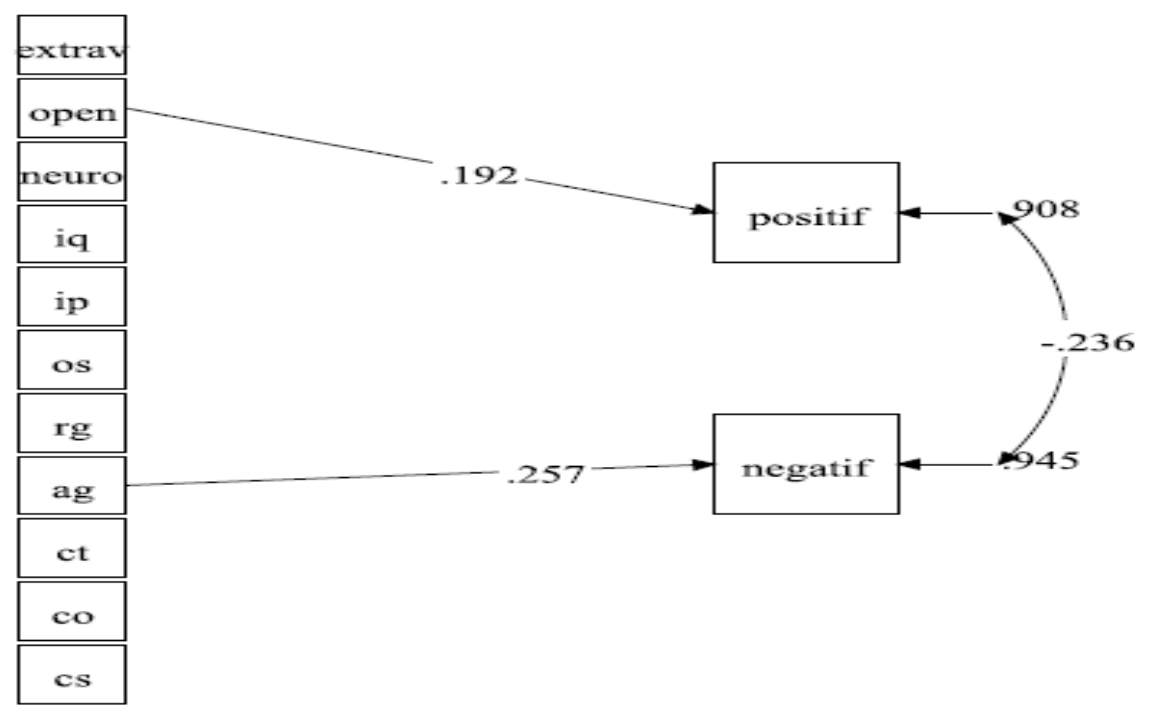


Other findings show that there is no part of the climate and organizational culture that affects a person's positive creativity. This means that in the group of government employees, whether a person is creative only depends on individual factors, namely personality type. In this case, people who have high positive creativity are only people who have high imagination, want to try new things, are not conventional thinking and are open to new views.

Meanwhile, the climate and organizational culture of government institutions did not have an effect on positive creativity. While the test results on negative creativity in government employees showed that negative creativity was not significantly influenced by all IVs $(R 2=0.055 ; \mathrm{p}>0.05)$. It's just that when viewed from the regression coefficient, creativity is negatively affected by achieving goal significantly with a coefficient of 0.257 . The coefficient which is positive indicates that high achieving goals will be followed by high negative creativity.

In contrast to positive creativity, negative creativity only depends on how the organizational culture works. Negative creativity will appear in organizations where each individual is encouraged to focus on achieving organizational targets. Achieving goals is important, but it turns out that government employees can trigger negative creativity like using any means provided the target is achieved.

\section{Creativity in Private Employees}

For private employees, more varied causes of positive creativity can be answered, as seen in Figure 5. Positive creativity in private employees depends on the personality and culture of the organization. Personality factors that significantly influence are extraversion (-0.187) and neuroticism (-0.164), both of which contribute in a negative direction. The organizational culture of the dimensions of coordinated teamwork (-0.316) and customer oriented (0.313), respectively, has a negative and positive contribution.

\section{Figure 5}

Path Diagram of Positive and Negative Creativity on Private Employees

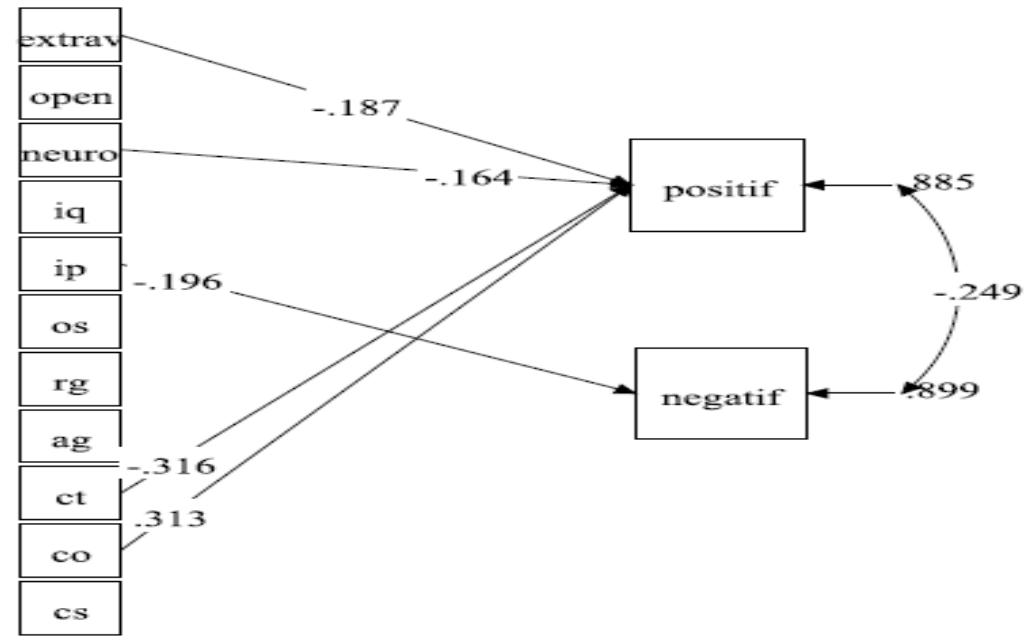


These results indicate that in private employees, positive creativity is low in people with sociable personalities and a lot of interaction with other people. In addition, it is also found in people who are sensitive, easily feel inferior, easy to panic and give up easily. Positive creativity appears in someone who enjoys solitude, does not enjoy socializing in large groups, is quiet, enjoys work that is done independently and has stable emotions.

When viewed from environmental factors, it is found that organizations that work more heavily on the values of individual and team collaboration / collaboration can suppress the emergence of positive creativity of their employees. In organizations with such a culture, decisions are often made by mutual agreement and employees do not have the flexibility to carry out their original ideas. In addition, the customer-oriented organizational culture variable turns out to be important in bringing out the positive creativity of its employees. In this study it was found that when the company focuses on efforts to meet the needs and expectations of its customers, positive employee creativity can emerge.

For private employees, negative creativity is only influenced by internal processes with a coefficient of -0.196 . The negative coefficient indicates that the negative creativity that exists in private offices can be suppressed by the internal processes that exist in the organization itself. Of the many causal variables, negative creativity in private employees only depends on one dimension of organizational climate, namely internal processes. This shows that negative creativity will emerge if the work climate is formal and adheres to a strong tradition in it. Formality and strong traditions in a company do not provide opportunities for new ideas / thoughts that are negative in nature.

\section{Conclussion}

This study aims to reveal the factors that influence the positive and negative creativity of government employees and private employees. The factors studied include internal factors (personality and intelligence) and external factors (organizational climate \& organizational culture). Based on the research results, it can be concluded that positive and negative creativity in the work environment can be influenced by individual factors and environmental factors. Testing on groups of private employees provides a clearer picture of the effect of these two factors.

From individual factors, it is found that intelligence does not have a significant effect on both the group of government employees and private employees. This shows that creativity in terms of outcomes as explained by James, Clark \& Cropanzano (1999) is not influenced by one's intelligence. This means that someone doing creativity positively or negatively has nothing to do with a person's intelligence level, but is influenced by the type of personality. As written by Puryear, Kettler \& Rinn, (2017) in their review article, the relationship between creativity and personality is also influenced by the conception of creativity itself. Based on the results of their study, it was also found that openess and extraversion personality types were strong predictors that influenced creativity positively. In line with the results of this study, which shows extraversion has a negative effect on the positive creativity of private employees and openess has a positive effect on the creativity of government employees.

From environmental factors, it was found that the organizational culture of coordinating teamwork and customer orientation had a significant effect on positive creativity, and organizational climate with nuances of formal relationships had a significant effect on negative creativity. This is shown by the 
results of testing on private employee groups that the organization is increasingly oriented towards customer satisfaction and allows to work independently / independently in the sense that it does not have to coordinate with other parties, which encourages the emergence of positive employee creativity. Meanwhile, the one that has a significant effect on negative creativity of private employees is the organizational climate which is weak in internal control and the formal structure / relationship in the system for mobilizing resources within the organization. The stronger the internal control of the organization in monitoring employee movements and the formal relationship between parties, the more it can suppress the emergence of negative employee creativity. Meanwhile, for government employees, there are no environmental factors that significantly influence positive creativity. Only found that organizational culture that emphasizes achieving targets has a positive influence on the negative creativity of government employees.

Based on the findings in this study, suggestions can be given to government agencies to develop a work culture that is not only oriented towards achieving the targets of a work unit or organization, but it is also important to pay attention to the processes undertaken to achieve these goals or targets. For example, by including standard operating procedures that can be carried out properly by all employees and accompanied by supervision so that goals can be achieved and the emergence of negative creativity can be avoided.

On the other hand, it is not surprising that private companies have made a culture that is oriented towards customer satisfaction their main value because it is able to generate positive innovations. Likewise, a culture of independence where every employee is given the freedom to work and develop their ideas independently, not depending on permits or long coordination which also influences the emergence of positive creativity. Meanwhile, to avoid negative creativity is to include internal supervision and control to ensure there is no violation or abuse.

From a theoretical point of view, measuring positive and negative creativity is still difficult to do, especially in Indonesian culture which is vulnerable to cultural norms, so it is susceptible to bias caused by social desirability. Therefore, it is recommended to conduct further scientific studies regarding its measurements, such as in the form of self-reports or measurements by third parties (Zare \& Flinchbaugh, 2019). Another thing that can be considered is the possibility of the presence of mediator variables, such as gender.

\section{References}

Amabile, T. M. (1988). A Model of Creativity an Innovations in Organizations. JAI Pres Inc, 10, 123-167.

An, C. (2019). The content and role of instrnsic motivation in creative work: The importance of seeking “enjoyment." Creativity Studies, 12(2), 280-290. https://doi.org/10.3846/cs.2019.6451

George, J. M., \& Zhou, J. (2007). Dual Tuning in a Supportive Context: Joint Contributions of Positive Mood, Negative Mood, and Supervisory Behaviors to Employee Creativity. The Academy of Management Journal, 50(3), 605-622.

Gino, F., \& Ariely, D. (2012). The dark side of creativity: Original thinkers can be more dishonest. Journal of Personality and Social Psychology, 102(3), 445-459. https://doi.org/10.1037/a0026406 
Guilford, J. (1986). Creative talents: Their nature, uses and developmen. Buffalo, NY Bearly.

Hair, J. F., W.C, Black., B.J, Babin., R.E, Anderson., \& R.L, Tatham. (2006). Multivariate Data Analysis (6th ed.). Pearson Education, Inc.

James, K., \& Asmus, C. (2001). Personality, Cognitive Skills, and Creativity in Different Life Domains. Creativity Research Journal, 13(2), 149-159. https://doi.org/10.1207/S15326934CRJ1302_3

James, K., Clark, K., \& Cropanzano, R. (1999). Positive and Negative Creativity in Groups, Institutions, and Organizations: A Model and Theoretical Extension. Creativity Research Journal, 12(3), 211-226. https://doi.org/10.1207/s15326934crj1203_6

John, O. P., \& Srivastava, S. (1999). The Big-Five trait taxonomy: History, measurement, and theoretical perspectives. Berkeley: University of California., 2, 102-138.

McLaren, R. B. (1993). The dark side of creativity. Creativity Research Journal, 6(1-2), 137-144. https://doi.org/10.1080/10400419309534472

Miller, G. F., \& Tal, I. R. (2007). Schizotypy versus openness and intelligence as predictors of creativity. Schizophrenia Research, 8.

Munandar, S. C. U. (1977). Creativity and Education. Disertasi Doktor U.I. Universitas Indonesia.

Muthen, L. K., \& Muthen, B. O. (2010). MPlus-Statistical analysis with latent variables- user's guide (6th ed.).

Patterson, M. (2009). Validating the organizational climate measure: Links to managerial practices productivity and innovation. Journal of Organizational Behavior, . 839-862.

Puryear, J. S., Kettler, T., \& Rinn, A. N. (2017). Relationships of personality to differential conceptions of creativity: A systematic review. Psychology of Aesthetics, Creativity, and the Arts, 11(1), 59-68. https://doi.org/10.1037/aca0000079

Sashkin, M., \& Rosenbach, W. E. (1996). Organizational culture assessment questionnaire. International and Pan American Copyright Conventions 1-12.

Timpe, A. D., \& Cikmat, S. (2002, copy right 2017). Kreativitas, Seri Ilmu dan Seni Manajemen Bisnis, Jakarta. PT. Elex Media Komputindo.

Vosburg, S. K. (1998). The Effects of Positive and Negative Mood on Divergent-Thinking Performance. Creativity Research Journal, 11(2), 165-172. https://doi.org/10.1207/s15326934crj1102_6

Zare, M., \& Flinchbaugh, C. (2019). Voice, creativity, and big five personality traits: A meta-analysis. Human Performance, 32(1), 30-51. https://doi.org/10.1080/08959285.2018.1550782 